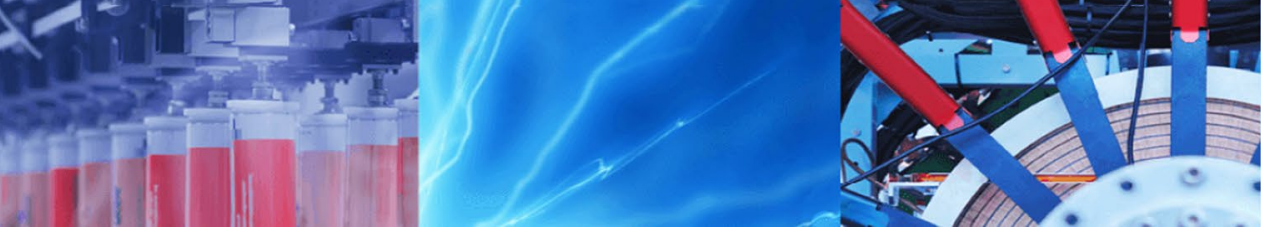

Research Article

\title{
Identification of groundwater potential zones in the hard and soft rock terrains of Kogi State, North Central Nigeria: an integrated GIS and remote sensing techniques
}

\author{
Stanley I. Ifediegwu ${ }^{1} \cdot$ Donald O. Nnebedum ${ }^{1} \cdot$ Alex N. Nwatarali ${ }^{2}$
}

() Springer Nature Switzerland AG 2019

\begin{abstract}
The availability of groundwater varies from region to region, place to place, sometimes within a few meters and even within the same geological formation. In the study area, an integration of various thematic maps such as geomorphologic, slope, drainage density, land use/land cover maps derived from remote sensing images, geological and lineament density maps and soil map helped in generation of groundwater potential zone map using the weighted overlay analysis in ArcGIS by assigning suitable weights on the Saaty's scale according to their importance in occurrence of groundwater. However, the assigned weights of the thematic layers and their features were then normalized by using AHP. The groundwater potential zones in the study area were grouped into four classes, and their distributions are: excellent (10.23\%), good (51.35\%), moderate (34.26\%) and poor (4.16\%). Excellent groundwater prospect map which covered only $10.23 \%$ of the study area falls within the lowlands and plains. For the accuracy of the groundwater potential zone map of the study area based on RS and GIS-based model, it was validated with the data on existing boreholes which was collated for 60 boreholes in the study area and shows positive correlation.
\end{abstract}

Keywords Geographic information system · Remote sensing · Kogi · Groundwater potential zone $\cdot$ Thematic layers

\section{Introduction}

Groundwater is among the valuable natural resources that support human health, economic development and ecological diversity $[7,28]$. It plays a key role in nature due to its natural quality, fairly well distributed and continuous availability. It has become major source of water supply for domestic, industrial and agricultural uses in both rural and urban settlements all over the nations [30]. However, groundwater has been accounted for more than $50 \%$ of humanity's freshwater for everyday uses and about 30\% of agricultural and industrial development [3]. Groundwater potential zone can be said to be a zone of saturation where water can be stored and transmitted in a large quantity. The occurrence and movement of groundwater in a hard rock terrain are controlled by degree of weathering and extent of fracturing of the bed rocks [11], while the quantity of groundwater in aquifer is governed by many factors, viz., topography, lithology, geological structures, lineament density, aperture and connectivity as well as primary and secondary porosity [20]. The identification of groundwater potential zone requires direct or indirect analysis of some observable hydrogeomorphic features such as geomorphology, slope, drainage density, land use/land cover, lineament density, geology and soil type.

Currently, groundwater is gaining more attention due to unplanned growth of urbanization, industrialization and ever-growing population which has led to increased demand for groundwater for domestic, industrial and agricultural uses. This alarming plight calls for cost-efficient

\footnotetext{
$\triangle$ Stanley I. Ifediegwu, ifestanley11@gmail.com | 'Department of Geology, Faculty of Physical Sciences, University of Nigeria, Nsukka, Nigeria. ${ }^{2}$ Department of Geology and Mining, Faculty of Applied Sciences, Enugu State University of Science and Technology, Enugu, Enugu State, Nigeria.
}

SN Applied Sciences (2019) 1:1151 | https://doi.org/10.1007/s42452-019-1181-1 


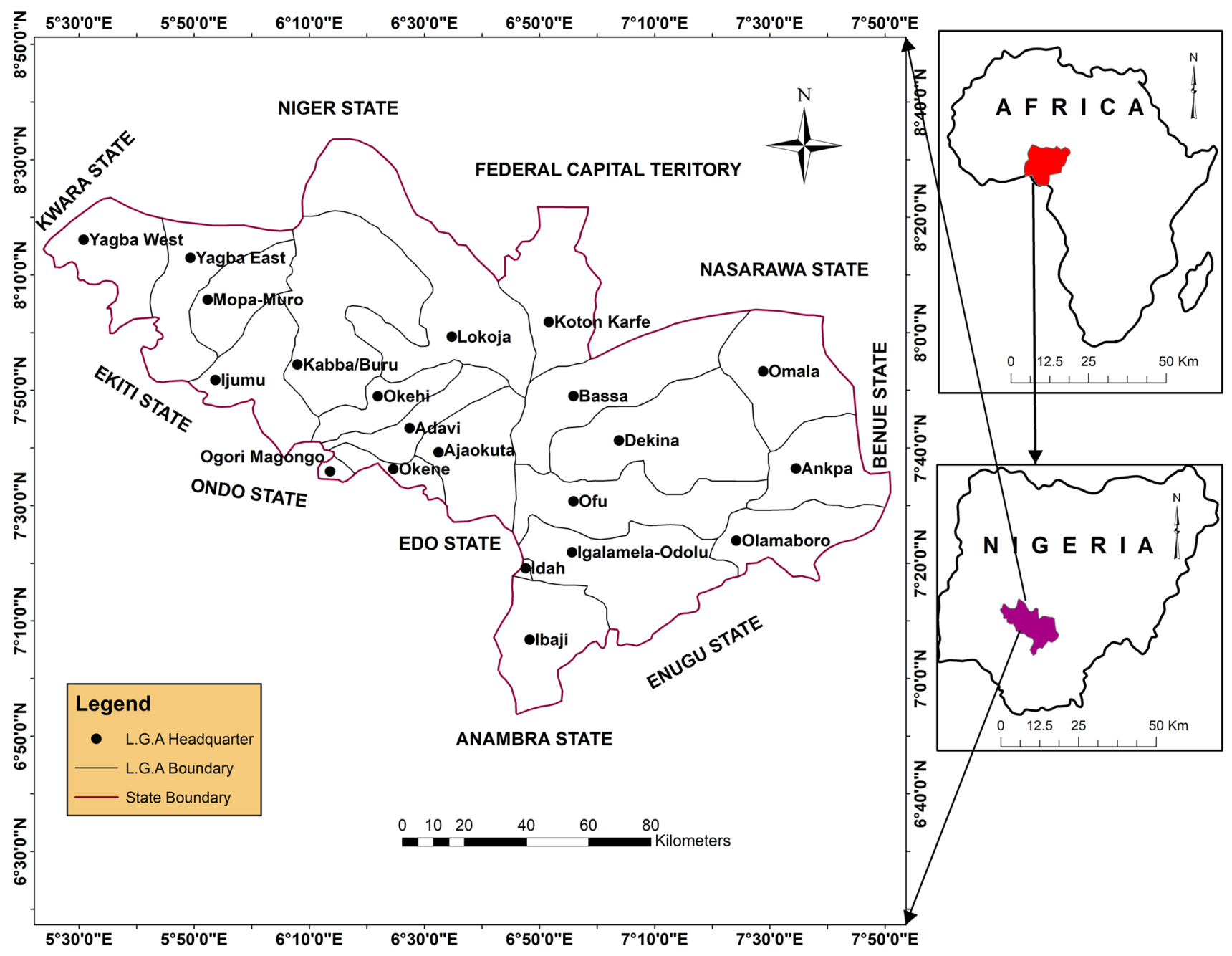

Fig. 1 Location map of the study area

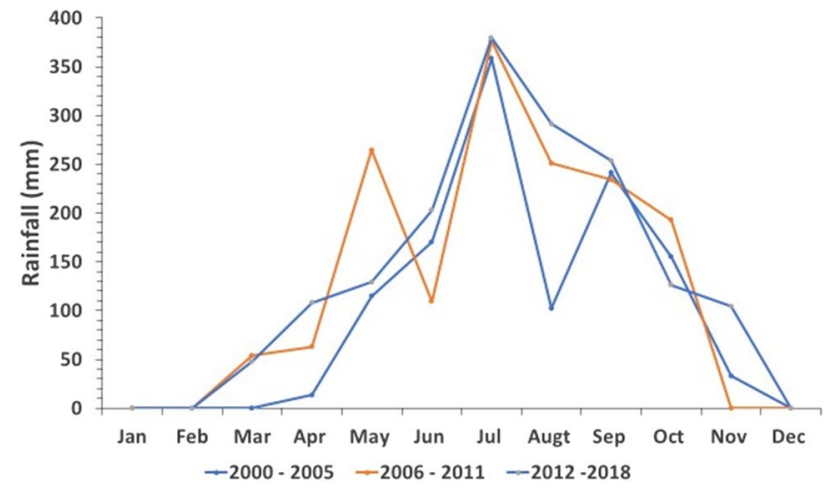

Fig. 2 Trend of mean annual rainfall within the area for 19 years

approach suitable for groundwater exploration for sustainable budgeting, management and development to eliminate water scarcity $[15,31]$. However, overexploitation of groundwater resources due to increasing population can lead to decline of groundwater levels and deterioration of groundwater quality.

Lacking a proper management of water resources, the focus solely on the identification of groundwater potential zones leads to increased overexploitation.

Consequently, the revolution in efficient, powerful and high-speed computers, the advent of remote sensing (RS) and geographic information system (GIS) offers a great platform and scope for integrating different hydrogeomorphic themes that can be used to identify groundwater potential zones of the present area. A combination of remote sensing (RS) and geographic information system (GIS) has proven to be an efficient tool in water resource studies $[14,17]$.

In the past, many researchers (from Nigeria and other countries) have used RS and GIS techniques to determine groundwater potential zone with successful results $[6,8$, $10,12,24]$. In these studies, the commonly used thematic 
Fig. 3 Flowchart of the methodology adopted in the study

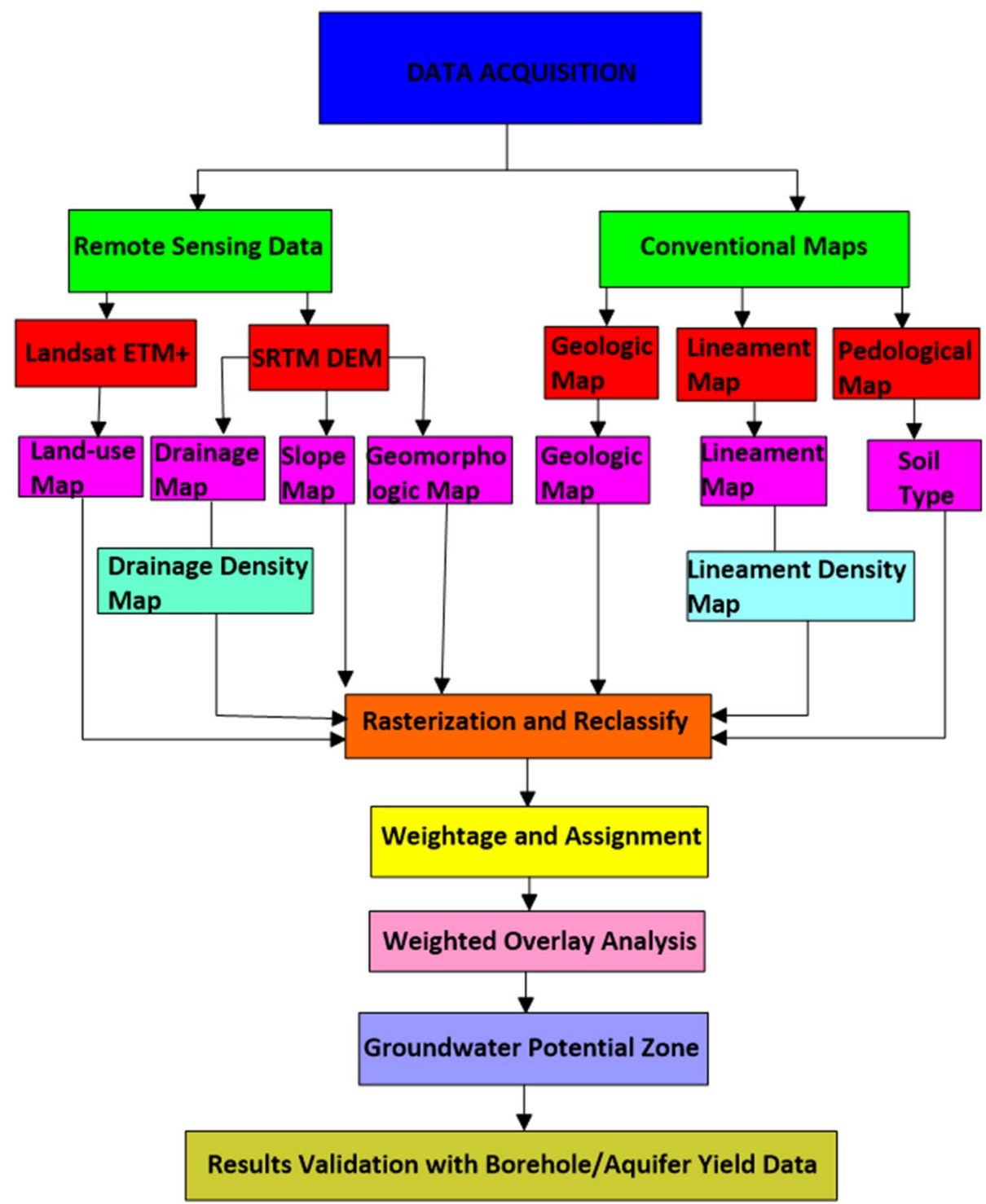

layers are geology, geomorphology, slope, soil type, land use/land cover, drainage density and lineament density.

In the study area, there is little or no existing work published on the use of integrated GIS and RS techniques in identification of groundwater potential zone. The existing work published centered on conventional methods such as geological, hydrogeological and geophysical approaches were employed for siting boreholes for water supply $[2,5,16,18,21-23]$. Population growth in Kogi State has raised concerns about the allocation of surface water flow and the increased demands for groundwater resources. To address these concerns, there is a need for improved methods for accurately accessing regional groundwater resources. Hence, the aim of this study is to identify groundwater potential zones of Kogi State, North Central Nigeria using GIS and RS techniques for proper management, development and planning with the following objectives: A; to prepare thematic layers, viz., geology, geomorphology, soil, slope, drainage density, land use/land cover, lineament density and rainfall, B; to delineate groundwater potential zones through integration of several thematic layers with GIS and RS techniques.

\section{The study area}

Kogi State lies between latitudes $6^{\circ} 30^{\prime} \mathrm{N}$ and $8^{\circ} 40^{\prime} \mathrm{N}$ and longitudes $5^{\circ} 10^{\prime} \mathrm{E}$ and $8^{\circ} 10^{\prime} \mathrm{E}$, encompassing the twentyone local government area of the state (Fig. 1). According census 2006, the population of the state has reached up to $3,314,043$ inhabitants and has an area of approximately $29,833 \mathrm{~km}^{2}$. The adjacent states are Federal Capital Territory, Nasarawa and Niger to the north, Edo, Anambra and 
Table 1 Pair-wise comparison matrices of the different thematic layers

\begin{tabular}{llllllll}
\hline Themes & GG & GM & ST & SL & LD & DD & LULC \\
\hline Geology (GG) & 1 & & & & & & \\
Geomorphology (GM) & 0.9 & 1 & & & & \\
Soil type (ST) & $1 / 2$ & 0.9 & 1 & & & \\
Slope (SL) & $1 / 4$ & $1 / 3$ & $1 / 2$ & 1 & & \\
Lineament density (LD) & $1 / 5$ & $1 / 4$ & $1 / 3$ & 0.9 & 1 & \\
Drainage density (DD) & $1 / 6$ & $1 / 5$ & $1 / 4$ & $1 / 2$ & 0.9 & 1 & \\
Land use/land cover (LULC) & $1 / 7$ & $1 / 6$ & $1 / 5$ & $1 / 3$ & $1 / 2$ & 0.9 & 1 \\
\hline
\end{tabular}

Table 2 Weights of a thematic map for groundwater potential zones

\begin{tabular}{lll}
\hline Themes & Assigned weights & $\begin{array}{l}\text { Normal- } \\
\text { ized } \\
\text { weights }\end{array}$ \\
\hline Geology & 7 & 0.3018 \\
Geomorphology & 6 & 0.2025 \\
Soil & 5 & 0.2087 \\
Slope & 4 & 0.1909 \\
Lineament density & 3 & 0.0910 \\
Drainage density & 2 & 0.0628 \\
Land use/land cover & 1 & 0.0451 \\
\hline
\end{tabular}

Enugu to the south, Benue to the east and Kwara, Ekiti and Ondo State to the west.

\subsection{Drainage, topography, climate and vegetation}

The topography of the area consists of a hilly plateau dipping gently in the northeastern and eastern directions down to the Niger River valley, while in the southwestern part of the area many hills overlooking the plateau are made up of Precambrian gneisses and granites and long ridges with gentle to steep slopes. The ground elevations range between 140 and $300 \mathrm{~m}$ above sea level.

The Kogi State climate is characterized by two seasons, namely rainy and dry seasons. The area records about 1839 millimeters average rainfall. The climate is generally cool during the raining season which lasts from March to October and relatively hot during the dry season. The dry season commences in November and lasts till April (Fig. 2). Average temperature is $28^{\circ} \mathrm{C}$. December and early January are coldest as a result of dry dusty harmattan winds [19]. The area has derived guinea savannah vegetation. The highlands are of semitropical rain forest type. It is characteristically green and is complemented by typical grassy vegetation. Fresh water swamp forests also occur in the area.

\subsection{Geology and hydrogeology of the study area}

The geology and hydrogeology of the area have been extensively studied by various researchers. Previous works on the stratigraphy, petrography and hydrogeology of the formations were carried out by Reyment $[1,4$, $9,13,25,26,29]$. The geology of Kogi State is made up of two major litho-petrological components, namely the Precambrian basement complex of North Central Nigeria, and sedimentary basins. The Precambrian basement complex of North Central Nigeria is made up of the migmatite-gneiss-quartzite complex (migmatite, gneisses, quartzite and quartz-schist and small lenses of calc-silicate rocks), the schist belts (migmatised to unmigmatised paraschist and meta-igneous and charnockitic rocks), the older granites (granodiorite to granite and potassic syenite) and unmetamorphosed dolerite dykes. The sedimentary basins, containing sediment fill of Cretaceous ages, comprise the Mid-Niger (Bida/Nupe) and Anambra basins. The sedimentary basins unconformably overlie the basement complex and consists of shale, siltstone and finegrained sandstones.

The distribution of groundwater is controlled by rock lithology, texture and structures and by hydrological (stream inflow) as well as meteorological factors such as rainfall.

In the study area, two types of aquifer are identifiable; one is deep unconfined condition, while the other is shallow semi-confined but locally confined in some places. The deep unconfined condition is most widespread and occupies about $80 \%$ of the land area underlain by sedimentary basins, while the shallow semi-confined and confined aquifers occur in the weathered mantle, fractured and/or faulted traces and are limited to small portions of the area. Depth to water table in the area varies from $3.4 \mathrm{~m}$ to above $60 \mathrm{~m}$. 


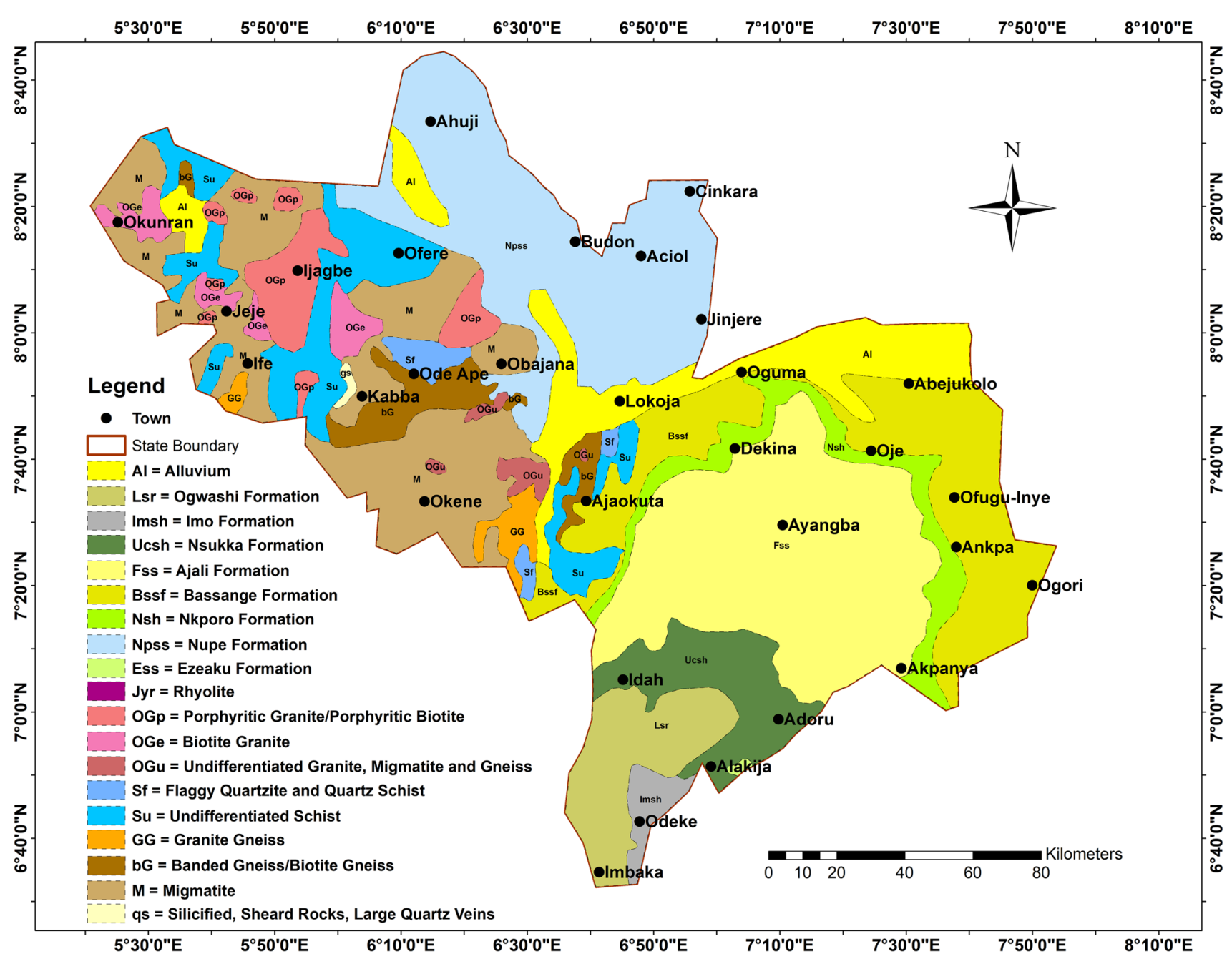

Fig. 4 Geologic map of the study area. (Modified from NGSA, 2006)

\section{Data used and methodology}

Remote sensing data which comprise of 90-m interval Shuttle Radar Topographic Mission (SRTM) Digital Elevation Model (DEM) and Landsat Enhanced Thematic Mapper plus (ETM+) alongside with conventional data such as geological, pedological and lineament, as well as meteorological and field observation data were used in this study (Fig. 3).

The Shuttle Radar Topographic Mission (SRTM) Digital Elevation Model (DEM) and Landsat Enhanced Thematic Mapper plus (ETM+) retrieved from earthexplorer.usgs.gov website has been used for the preparation of thematic layers of geomorphology, drainage density, slope and land use/land cover using ArcGIS 10.5 software platform.

However, the analogue maps of geology, lineament and soil obtained from Nigeria Geological Survey Agency (NGSA) and (FAO/UNESCO/IS-RIC) with a scale of 1:250,000 have been converted to digital format by scanning in Tiff
Format and geo-referenced into Universal Transverse Mercator (UTM-Zone $32 \mathrm{~N}$ ) and datum WGS-1984. These maps were further updated using satellite data. Furthermore, the thematic layers of geology, geomorphology, soil, lineament density, slope, land use/land cover and drainage density were used for the evaluation of groundwater potential zone of the study area. All these thematic layers were converted into raster layers and superimposed by weighted overlay in ArcGIS environment. Each layer was assigned a rank and weightage of 1-4 according to their availability of groundwater occurrence. Moreover, the normalized weights of each of the thematic layer were calculated with the aid of pair-wise comparison matrix as adopted by [27] analytical hierarchy process (Tables 1, 2).

The groundwater potential zone (Fig. 6) was mathematically calculated using ArcGIS raster analysis as follows:

$$
\begin{aligned}
\mathrm{GWP}= & \left(\mathrm{GG}_{w} \mathrm{GG}_{W_{\mathrm{i}}}+\mathrm{GM}_{w} \mathrm{GM}_{\mathrm{Wi}}+\mathrm{ST}_{w} \mathrm{ST}_{\mathrm{Wi}_{\mathrm{i}}}+\mathrm{SL}_{w} \mathrm{SL}_{\mathrm{Wi}}\right. \\
& \left.+\mathrm{LD}_{w} \mathrm{LD}_{\mathrm{Wi}_{\mathrm{i}}}+\mathrm{DD}_{w} \mathrm{DD}_{\mathrm{Wi}_{\mathrm{i}}}+\mathrm{LULC}_{w} \mathrm{LULC}_{\mathrm{Wi}_{\mathrm{i}}}\right)
\end{aligned}
$$




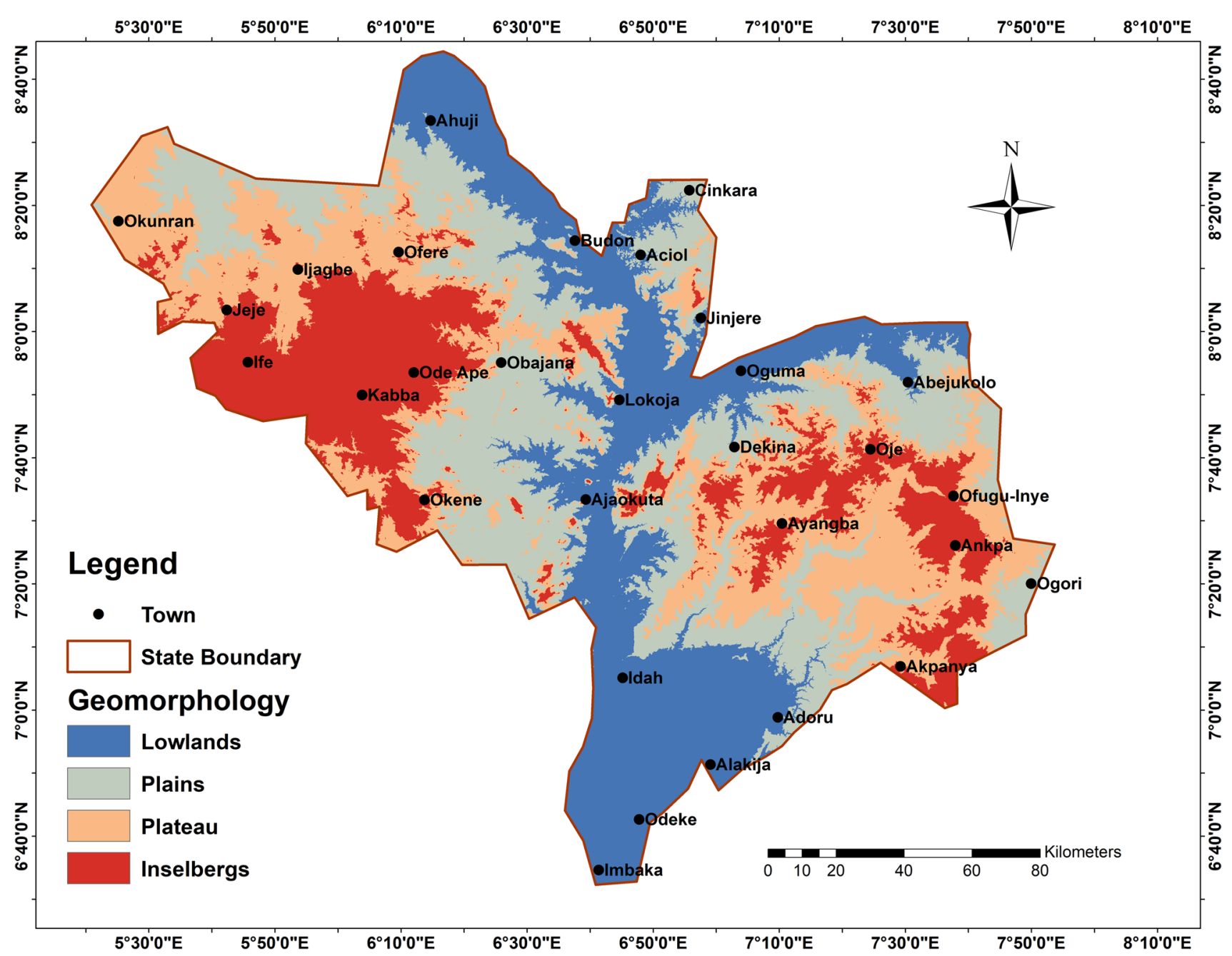

Fig. 5 Geomorphologic map of the study area

where $\mathrm{GG}=$ geology, $\mathrm{GM}=$ geomorphology, $\mathrm{ST}=$ soil type, $\mathrm{SL}=$ slope, $\mathrm{LD}=$ lineaments density, $\mathrm{DD}=$ drainage density, LULC = land use/land cover, $w=$ normalized weight of a theme and $\mathrm{Wi}=$ normalized weight of individual classes.

Finally, the results were validated with existing borehole yield data. Figure 2 shows the illustration of the methodology of the study.

\section{Results and discussion}

\subsection{Geology}

The study area is underlain by the Precambrian basement complex rocks of North Central and Cretaceous-Quaternary sedimentary rocks of Southeastern and Northwestern Nigeria, respectively (Fig. 4). The basement complex rocks of North Central Nigeria comprise igneous and metamorphic rock units (migmatite-gneiss complex, meta-sedimentary and volcanic series, pan-African older granitoids and per-alkaline younger granitoids). However, the sedimentary rock units of Southeastern and Northwestern Nigeria consist of Anambra and Mid-Niger (Bida/ Nupe) Basins and associated with shale, siltstone, claystone, mudstone, limestone, ironstone and sandstone.

In accordance with the intricacy of the tectonic evolution of the basement complex and sedimentary rocks, several studies have identified the geology and categorization of the Basement and sedimentary rocks of North Central Nigeria. The research conducted by $[26,30]$ on the geology of North Central Nigeria classified the basement complex rocks into five major rock types and the sedimentary rocks into seven geological formations:

(a) Tectonic units (silicified, sheared rocks, large quartz veins). 


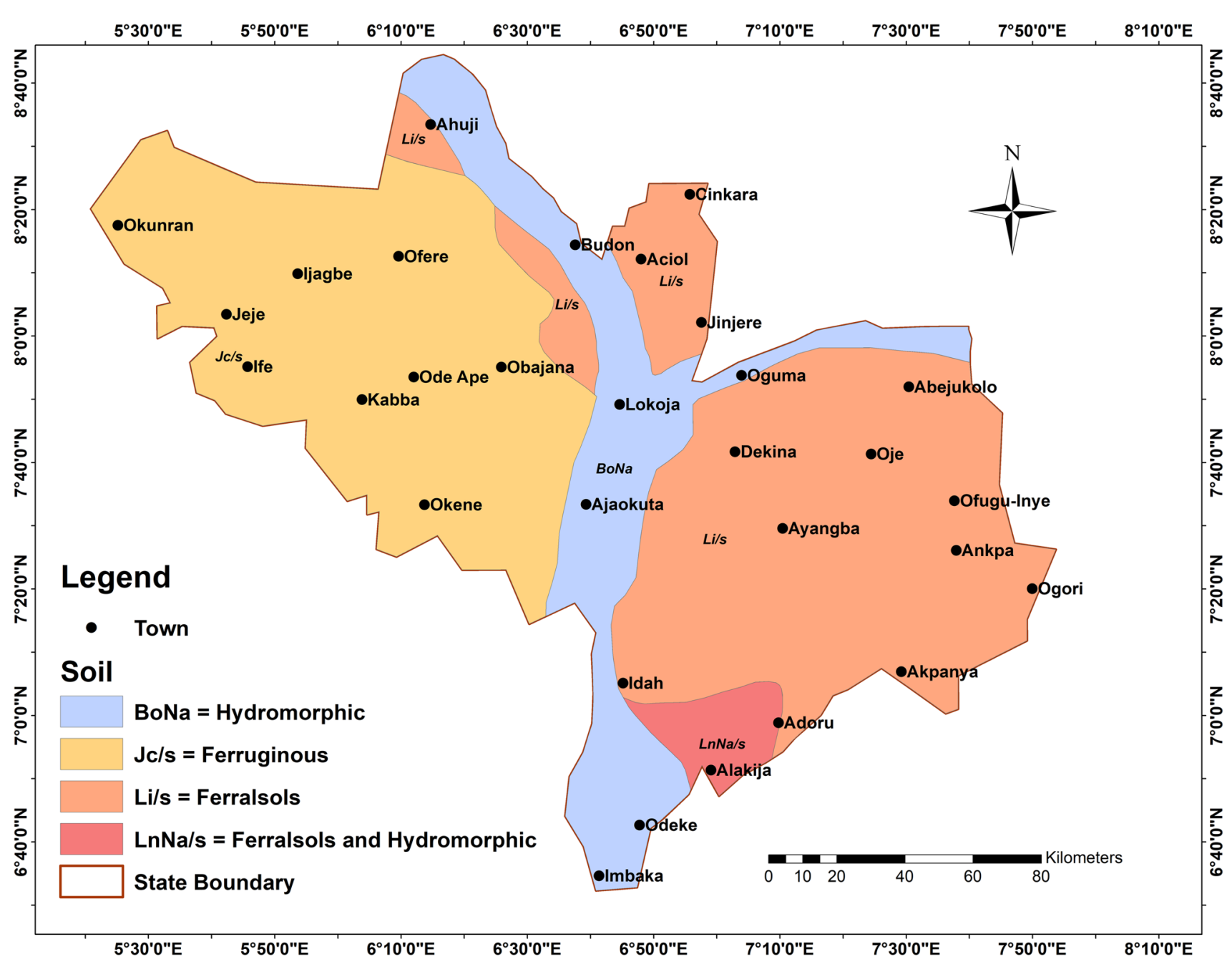

Fig. 6 Soil map of the study area

(b) Migmatite-gneiss complex.

(c) Meta-sediment/volcanic series.

(d) Pan-African older granitoids.

(e) Per-alkaline younger granitoids.

(f) Gundumi formation.

(g) Nupe formation.

(h) Nkporo formation.

(i) Bassange formation.

(j) Nsukka formation.

(k) Imo formation.

(l) Ogwashi formation.

In the northwestern portion of the study area, the massive unfractured lithological units in the basement complex have little control on the occurrence of groundwater except in a case where secondary porosity has taken place through the development of fissures, water-filled pores, weathered overburden or fractured rock units which in turn form the groundwater potential zones. Meanwhile, in the northeastern and southeastern parts of the area which is made up of sedimentary rocks has more influence on groundwater availability especially, in cases of primary and secondary porosity.

Hence, based on groundwater availability, appropriate weights are assigned to different rock units of the study area. Sandstone was assigned high weightage due to its highest porosity followed by quartzite, shale and limestone which was assigned moderate weights due to their moderate porosity as a result of fracturing, faulting and jointing. Low value was assigned to migmatite/ gneisses, biotite granite and schist/metasediments due to their resistance to weathering, faulting and jointing in the area. The lithological units were reclassified according to weights generated (Table 2). 


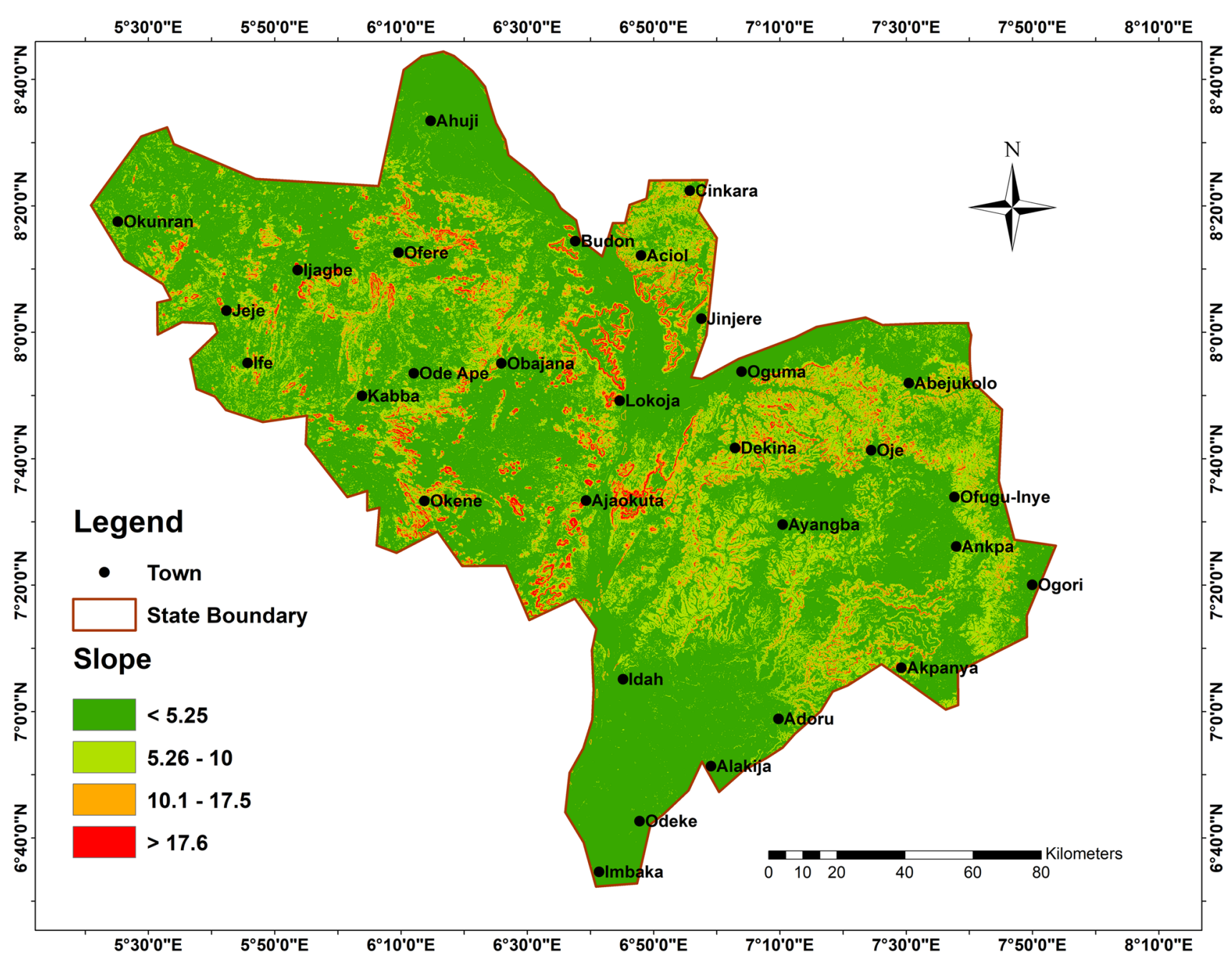

Fig. 7 Slope map of the study area

\subsection{Geomorphology}

According to [12], hydrogeomorphology is the study of various landform and drainage characteristics that could have a direct control on the occurrence and flow of groundwater. The geomorphologic units of the area can be divided into lowlands, plains, plateau and inselbergs (Fig. 5). Among these, lowlands and plains covering about $9946 \mathrm{~km} / \mathrm{km}^{2}$ (33.34\%) and $7855 \mathrm{~km} / \mathrm{km}^{2}$ $(26.33 \%)$ are very good locations for groundwater targeting; therefore, they were assigned high weightage due to its moderate to low runoff. In the study area, western and eastern sides which constitute about $7543 \mathrm{~km} /$ $\mathrm{km}^{2}(25.28 \%)$ are covered by inselberg hills. The shallow aquifer in the inselberg hill area has moderate to poor groundwater potentials; hence, it was assigned low weightage. Ridges are seen in the northwestern and southeastern sections of the area covered about $4489 \mathrm{~km} / \mathrm{km}^{2}$ (15.05\%).

\subsection{Soil}

As indicated in Fig. 6, four types of soils are generally seen in the study area, namely hydromorphic, ferruginous, ferralsols and hydromorphic and ferralsols. Ferralsols soil constitutes about $14,879 \mathrm{~km} / \mathrm{km}^{2}(49.87 \%)$ and is the predominant soil in the study area. However, the ferruginous soils are seen in the western portion of the area and spread over $9975 \mathrm{~km} / \mathrm{km}^{2}$ (33.44\%). Hydromorphic soil which covered an area extent of about $2986 \mathrm{~km} / \mathrm{km}^{2}(10.01 \%)$ is seen all along the banks of Niger and Benue Rivers. According to their influence on groundwater occurrence, ferralsols and hydromorphic soils have high water holding capacity; therefore, they were assigned high weightage.

\subsection{Slope}

Based on geomorphologic features, slope is among the mechanisms that govern groundwater recharge and 


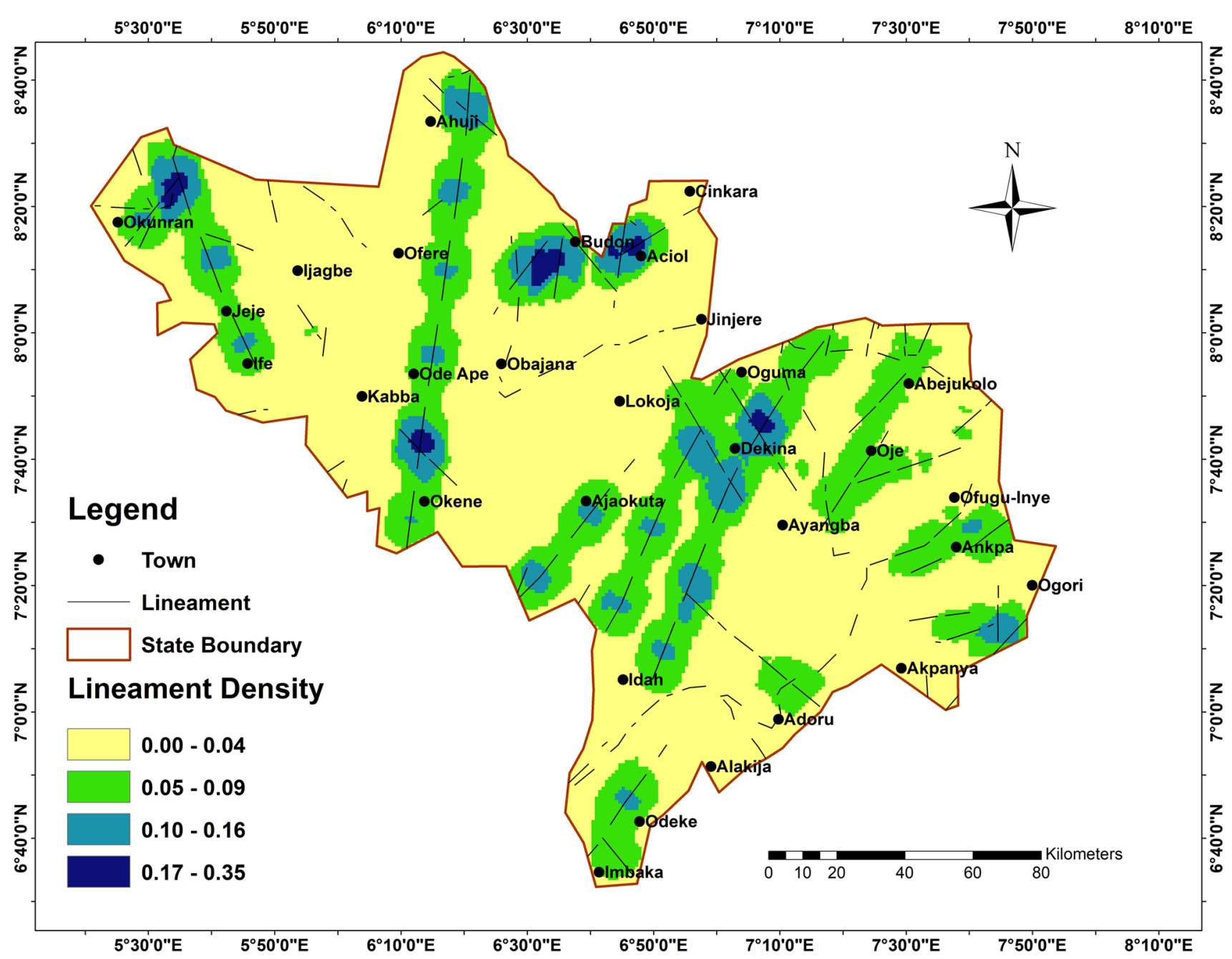

Fig. 8 Lineament density map of the study area

percolation; however, the nature of slope of an area alongside with other geomorphic features determines the occurrence of groundwater. Similarly, slope map of an area plays a vital role in determination of groundwater recharge as it is influenced by rate of surface water infiltration. In the area with low slope, surface water runoff is low, therefore encouraging longer residence time for rainwater to infiltrate and percolate within the subsurface material, while high slope regions favor high surface runoff with short residence time for infiltration and percolation. In the study area, slope is classified on percentage basis as $<5.25,5.25-10,10.1-17.5,>17.5$ designed as nearly level, gently sloping, moderately sloping and steeply sloping (Fig. 7). Most of the study area belongs to nearly level and gently sloping category $(<5.25$ and $5.25-10 \%)$. The dominance of the nearly level and gently slope classes is favorable while considering the groundwater potential, and they were assigned high weightage.

\subsection{Lineament density}

Lineament density is an important hydrogeomorphic parameter in groundwater studies. The thematic layers of lineament density map of the study area revealed four main lineament density classes: $0.00-0.04 \mathrm{~km} / \mathrm{km}^{2}$ (low); $0.05-0.09 \mathrm{~km} / \mathrm{km}^{2}$ (moderate); $0.10-0.16 \mathrm{~km} / \mathrm{km}^{2}$ (high) and $0.17-0.35 \mathrm{~km} / \mathrm{km}^{2}$ (very high). It is apparent from Fig. 8 that the majority of the study area is dominated by low lineament density constituting about $21.068 \mathrm{~km} /$ $\mathrm{km}^{2}$ (70.62\%). Meanwhile, area with very high lineament density covers only about $562 \mathrm{~km} / \mathrm{km}^{2}(1.88 \%)$ and they are seen in the region underlain by zones of localized weathering which enhances permeability and porosity. Moreover, moderate to high lineament density constitutes about $7130 \mathrm{~km} / \mathrm{km}^{2}$ (23.90\%) and $1073 \mathrm{~km} / \mathrm{km}^{2}$ (3.60\%), respectively. 


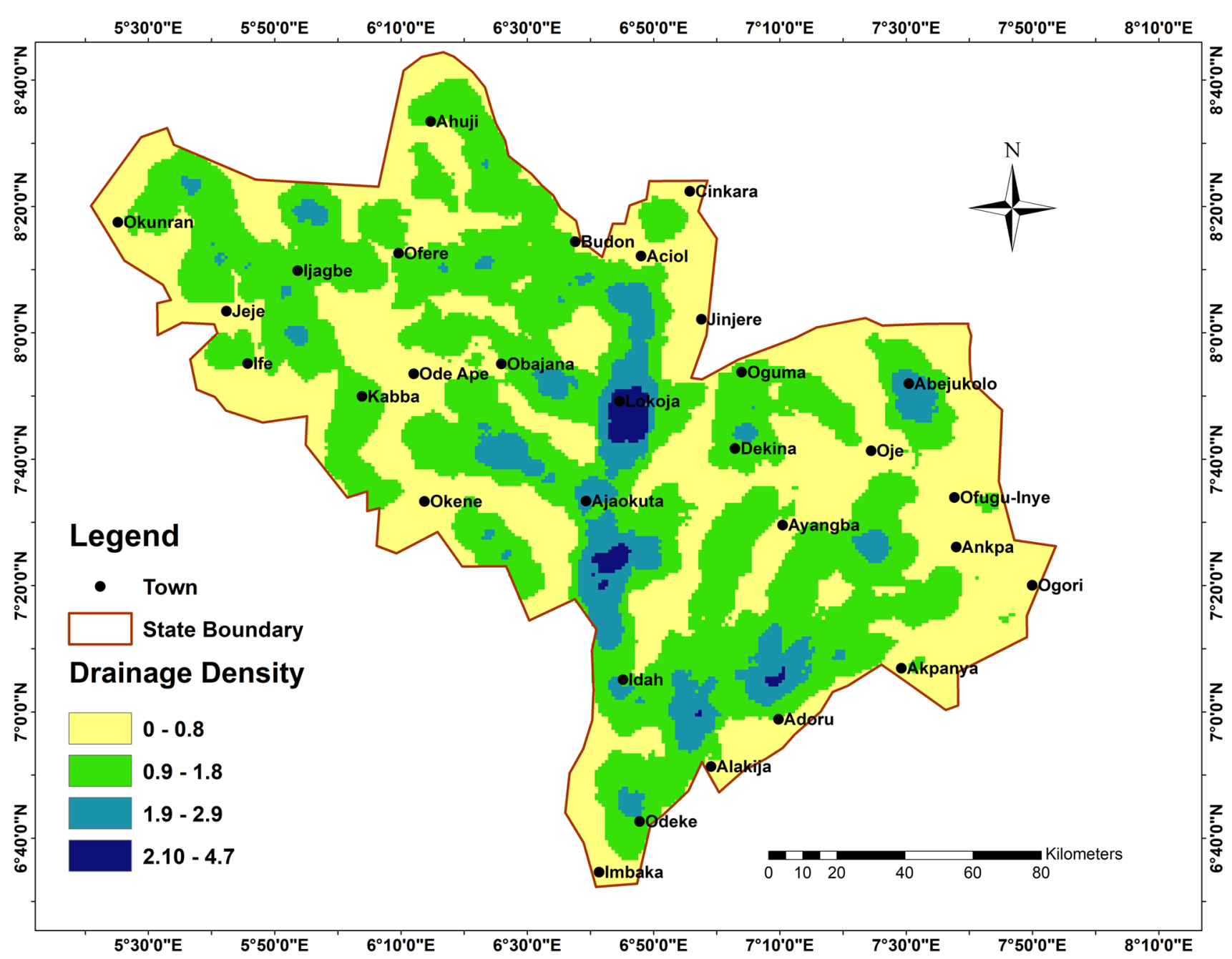

Fig. 9 Drainage density map of the study area

\subsection{Drainage density}

Drainage basin with low drainage density $\left(\mathrm{km} / \mathrm{km}^{2}\right)$ shows that a large quantity of the rainfall infiltrates within the subsurface lithology. Consequently, drainage density is one the important factors that determines groundwater potential zones as it give ideas on the amount of rainfall percolation relative to runoff, slope, presence of morphological features and the subsurface formations within an area. However, it has also been observed that a low drainage density is more likely to occur in area of highly permeable subsurface lithology under nearly level to gently slope where relief is low, while high drainage density is the resultant of impermeable subsurface materials, inselberg relief, low lineaments and high slope.
In the study area, the drainage density map was grouped into four classes which are 0-0.8 (low); 0.8-1.8 (moderate); 1.8-2.9 (high) and 2.9-4.7 (very high) (Fig. 9). Low drainage density values ranging from 0 to 0.8 were observed in the area where morphological features depict very lowland and plain surface and have very high infiltration capacity and yields preferable groundwater potentials. Area with very high drainage density that covers about $809 \mathrm{~km} / \mathrm{km}^{2}$ (2.71\%) was given lower weightage as compared to the area with low drainage density which was assigned high weightage and account for about $18,641 \mathrm{~km} / \mathrm{km}^{2}$ (62.48\%). Moreover, moderate and high drainage density constitutes about $8946 \mathrm{~km} / \mathrm{km}^{2}$ (29.99\%) and $1437 \mathrm{~km} / \mathrm{km}^{2}(4.82 \%)$, respectively, and implies low or moderate groundwater recharge potentials for approximately $75 \%$ of the study area. 


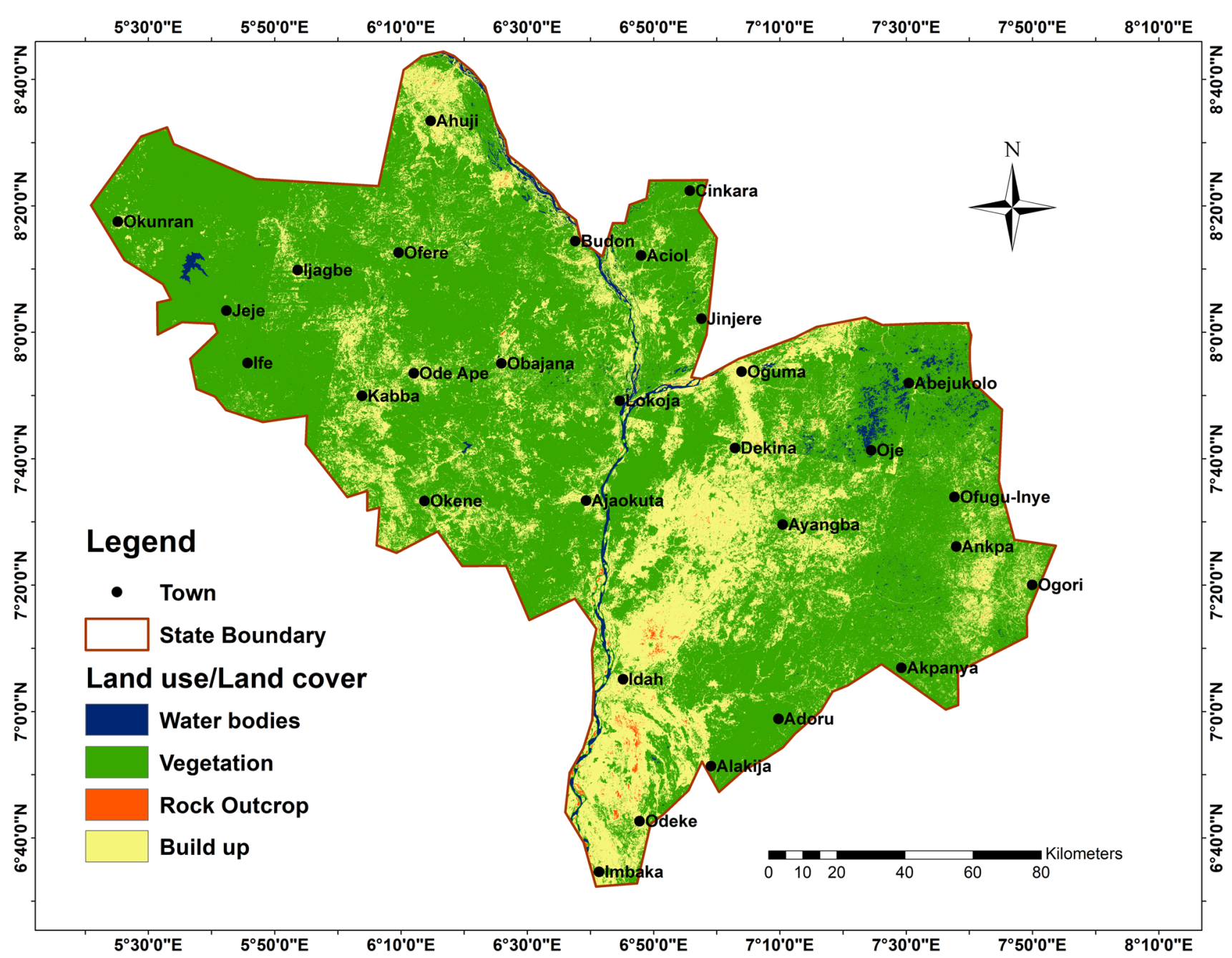

Fig. 10 Land use/land cover map of the study area

\subsection{Land use/land cover}

Land use/land cover map as presented in Fig. 10 reveals that the study area is made up of vast vegetation, waterlogged, build up and rock outcrop. Table 1 shows that vegetation and water bodies accounted for $22,305 \mathrm{~km} / \mathrm{km}^{2}$ (74.21\%), whereas built-up area and rock outcrop covered $7156 \mathrm{~km} / \mathrm{km}^{2}$ (24.38\%) and $372 \mathrm{~km} / \mathrm{km}^{2}$ (0.96\%), respectively. The dominance of vegetal cover could be attributed to widespread of agricultural practice in the study area. Vegetation and waterlogged areas are good for groundwater infiltration, and therefore, they were given high weightage.

\subsection{Characterization of groundwater potential zones}

Groundwater potential zones of the area were generated from assignment and normalized weighting of the separate features of the thematic layers, viz., geology, geomorphology, soil type, slope, lineament density, drainage density and land use/land cover maps (Table 3 ).

As displayed in Fig. 11, the groundwater potential zones map of the study area shows four distinct zones, namely poor, moderate, good and excellent zones. The groundwater map of the study area revealed that western section of the area which covers about $10,634.62 \mathrm{~km} / \mathrm{km}^{2}$ (38.4\%) indicates poor to moderate groundwater recharge 
Table 3 Assigned and normalized weights of different parameter for groundwater potential zones

\begin{tabular}{|c|c|c|c|c|c|c|}
\hline Categories & Criterion & Weight & $\begin{array}{l}\text { Normalized } \\
\text { weight }\end{array}$ & Rank & Area $\left(\mathrm{km}^{2}\right)$ & Percentage area \\
\hline \multirow[t]{5}{*}{ Geology } & Sandstones & 5 & 0.2906 & 0.231 & 11,436 & 38.33 \\
\hline & Quartzite & 4 & 0.2564 & & 687 & 2.30 \\
\hline & Schist and metasediments & 3 & 0.1981 & & 2295 & 7.69 \\
\hline & Granitic rocks & 2 & 0.1253 & & 5594 & 18.75 \\
\hline & Migmatite/gneiss & 1 & 0.1006 & & 9821 & 32.92 \\
\hline \multirow[t]{4}{*}{ Geomorphology } & Lowlands & 4 & 0.4809 & 0.154 & 9946 & 33.34 \\
\hline & Plains & 3 & 0.3267 & & 7855 & 26.33 \\
\hline & Ridges & 2 & 0.3012 & & 4489 & 15.05 \\
\hline & Inselbergs & 1 & 0.1935 & & 7543 & 25.28 \\
\hline \multirow[t]{4}{*}{ Soil } & Hydromorphic & 4 & 0.5091 & 0.138 & 2986 & 10.01 \\
\hline & Ferruginous & 3 & 0.4623 & & 9975 & 33.44 \\
\hline & Ferralsols & 2 & 0.2760 & & 14,879 & 49.87 \\
\hline & Ferralsols and hydromorphic & 1 & 0.1986 & & 987 & 3.31 \\
\hline \multirow[t]{4}{*}{ Slope } & $<5.25$ & 4 & 0.1042 & 0.130 & 14,547 & 48.76 \\
\hline & $5.25-10$ & 3 & 0.1020 & & 7869 & 26.38 \\
\hline & $10.1-17.5$ & 2 & 0.0973 & & 4549 & 15.25 \\
\hline & $>17.6$ & 1 & 0.0249 & & 2868 & 9.61 \\
\hline \multirow[t]{4}{*}{ Lineament density } & $0.00-0.04$ & 1 & 0.2013 & 0.128 & 21,068 & 70.62 \\
\hline & $0.05-0.09$ & 2 & 0.1572 & & 7130 & 23.90 \\
\hline & $0.10-0.16$ & 3 & 0.1308 & & 1073 & 3.60 \\
\hline & $0.17-0.35$ & 4 & 0.1164 & & 562 & 1.88 \\
\hline \multirow[t]{4}{*}{ Drainage density } & $0-0.8$ & 4 & 0.4011 & 0.115 & 18,641 & 62.48 \\
\hline & $0.8-1.8$ & 3 & 0.3104 & & 8946 & 29.99 \\
\hline & $1.8-2.9$ & 2 & 0.2832 & & 1437 & 4.82 \\
\hline & $2.9-4.7$ & 1 & 0.2348 & & 809 & 2.71 \\
\hline \multirow[t]{4}{*}{ Land use/land cover } & Rock outcrop & 1 & 0.2718 & 0.100 & 372 & 0.96 \\
\hline & Settlements & 2 & 0.3125 & & 7156 & 24.38 \\
\hline & Water bodies & 3 & 0.3694 & & 1584 & 6.62 \\
\hline & Vegetations & 4 & 0.4276 & & 20,721 & 67.59 \\
\hline
\end{tabular}

potentials, whereas the northern and southern portions of the study area exhibit good groundwater recharge potential zones and constituting an area extent of approximately $14,539.30 \mathrm{~km} / \mathrm{km}^{2}$ (51.35\%). Consequently, the eastern part of the area which spread about $4659.13 \mathrm{~km} /$ $\mathrm{km}^{2}(10.23 \%)$ revealed excellent groundwater recharge potential zones (Table 4). However, a closer look at the groundwater potential map of the study area revealed that excellent potential zones occurred in the area underlain by false-bedded sandstone within the Anambra Basin in addition to low drainage density, gently slope, ferralsols type of soil and plain surface. Moreover, areas underlain by migmatite and gneiss specifically the western part of the area is characterized by low rainfall, ferruginous soil type, relatively high drainage density, steep slope and inselberg geomorphology have poor to moderate groundwater potentials. On the other hand, northern and southern portions of the study area underlain by shale, clay, ironstone, mudstone, quartz-schist, feldspathic sandstone and quartzite and characterized by steep slope, hydromorphic soil type, ridges and moderate lineament density exhibit moderate groundwater potential zones.

\subsection{Verification with borehole yield data}

The accuracy of the groundwater potential zone map of the study area based on RS and GIS-based model was validated by the data on existing boreholes (yield, depth and saturated thickness) and was collated for 60 boreholes in the study area (Table 5).

Generally, the depth of boreholes across the study area varied from 30.0 to $185.9 \mathrm{~m}$ within the area underlain by 


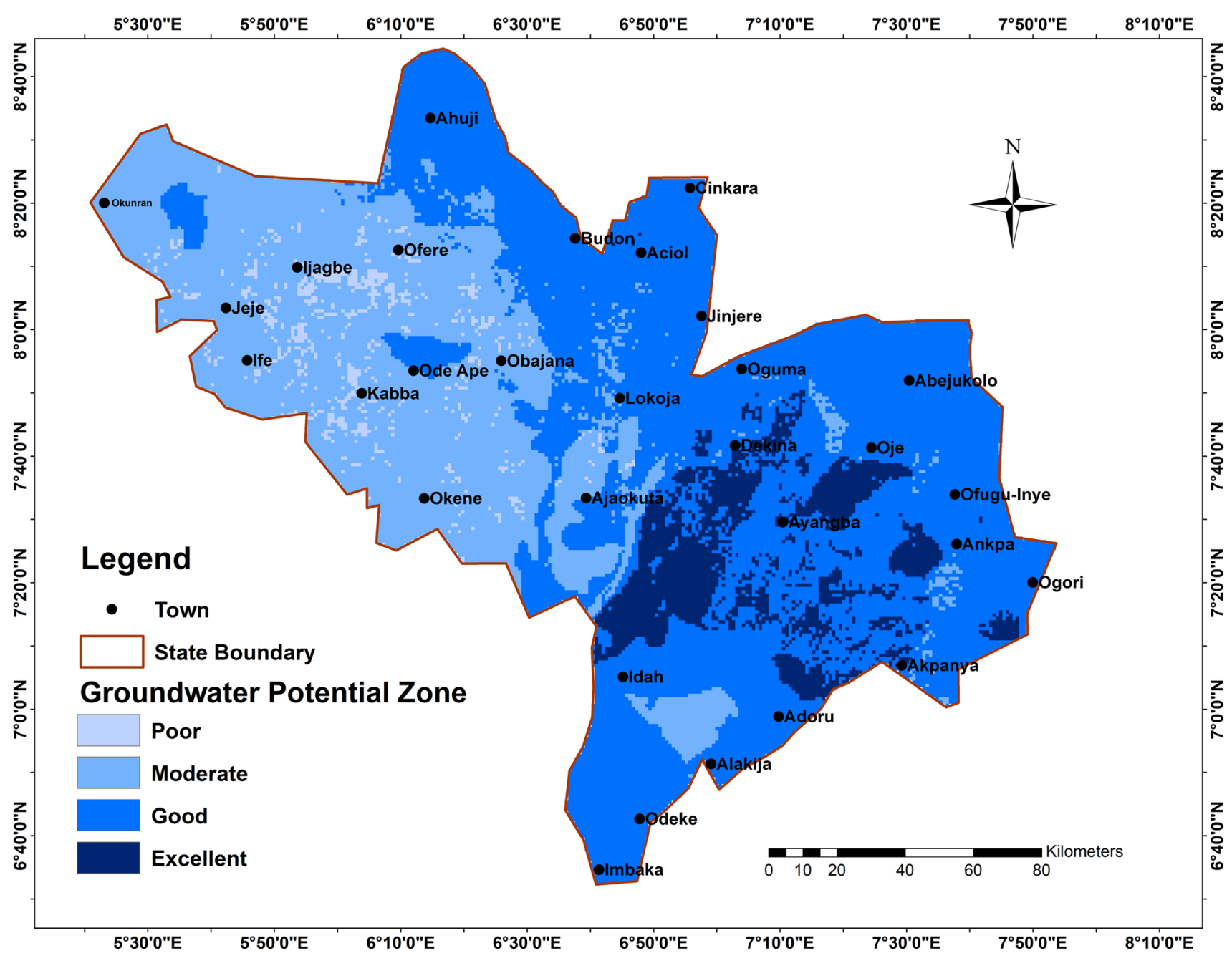

Fig. 11 Groundwater potential zone map of the study area

sedimentary rocks and from 25.3 to $95.0 \mathrm{~m}$ in the area underlain by basement complex. At the same time, saturated thickness fluctuates between $7.3 \mathrm{~m}$ in the magmatic/ gneiss terrains, $4.8 \mathrm{~m}$ in the granitic rock environments and $36.7 \mathrm{~m}$ in the quartzite/quartz-schist settings and from $82.3 \mathrm{~m}$ in the false-bedded sandstone terrains to $33.2 \mathrm{~m}$

Table 4 Distribution of groundwater potential zones, area extent and yield classification

\begin{tabular}{lcrl}
\hline $\begin{array}{l}\text { Groundwater } \\
\text { potential zone }\end{array}$ & Area (\%) & Area $\left(\mathrm{km}^{2}\right)$ & Yield classification \\
\hline Poor & 4.16 & 2357.07 & Poor $\left(<55 \mathrm{~m}^{3} /\right.$ day $)$ \\
Moderate & 34.26 & 8277.55 & Moderate $\left(155 \mathrm{~m}^{3} /\right.$ day $)$ \\
Good & 51.35 & $14,539.30$ & Good $\left(255 \mathrm{~m}^{3} /\right.$ day $)$ \\
Excellent & 10.23 & 4659.13 & Excellent $\left(>225 \mathrm{~m}^{3} /\right.$ day $)$ \\
\hline
\end{tabular}

in the sandy-shale environments. Consequently, the borehole yields range from 26 to $226 \mathrm{~m}^{3} /$ day in the migmatite/ gneiss areas, $44-100 \mathrm{~m}^{3} /$ day in the granitic rock terrains, $57-350 \mathrm{~m}^{3} /$ day in the quartzite/quartz-schist settings, $100-530 \mathrm{~m}^{3} /$ day in the false-bedded sandstone units and from 65 to $480 \mathrm{~m}^{3} /$ day in the sandy-shale environments.

However, the data from existing boreholes were superimposed on the groundwater potential zones map and various boreholes with different yields varied for distinct groundwater potential zones were delineated. Figure 12 displays the frequency distribution of different groundwater depths, saturated thickness and yields in the various terrains.

Finally, the accuracy of the groundwater potential zone map and the data obtained from existing boreholes of the study area reveal positive correlation. 


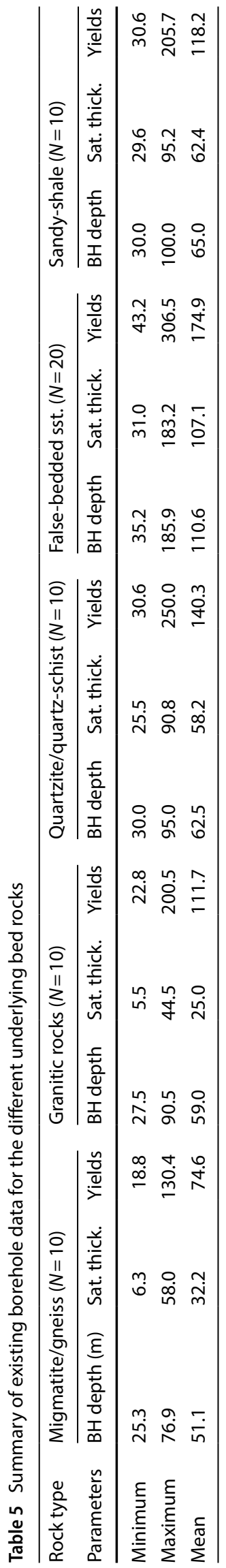

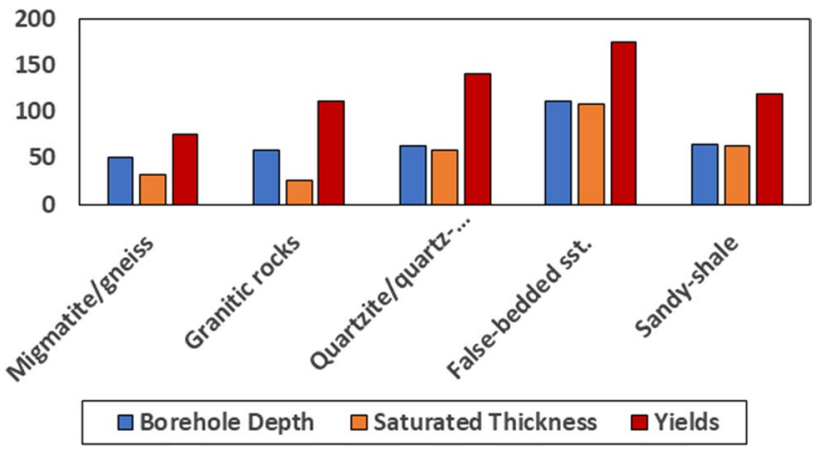

Fig. 12 Groundwater depth, saturated thickness and yields in different geological settings of the study area

\section{Conclusion}

Identification of groundwater potential zones in Kogi State was conducted utilizing GIS and remote sensing techniques that provided an effective methodology in the context of time and cost. Thematic layers of geology, geomorphology, soil type, lineament density, slope, drainage density and land use/land cover maps were integrated on a GIS environment employing the weighted overlay method.

The groundwater potential zones of the study area are the cumulative weightage of all the thematic layers, and the categorization comprises the pertinent availability of groundwater, the more the weight score, the higher the groundwater potential. The groundwater potential map of the study area was grouped into four classes, and their distributions are: excellent (10.23\%), good (34.26\%), moderate (51.35\%) and poor (4.16\%). The result shows that the excellent groundwater potential zone is restrained to only $10.23 \%$ of the study area, in lowlands and plains. The generalized groundwater potential map indicates the prevailing control of geology and other hydrogeomorphologic characteristics in the identification of groundwater potential zones; the areas underlain by banded migmatite/gneisses, biotite granite, porphyritic biotite/granitic and schist/ metasediments are characterized by moderate to poor groundwater potentials when compared to areas with good and excellent potentials which is characterized by Cretaceous to Quaternary sedimentary bedrocks as well as fractured/weathered quartzite and quartz-schist bedrock settings.

Consequently, the verification of groundwater potential map with existing borehole data in the area showed a positive correlation. As per Table 4, it can see that the borehole yields between 156 and $255 \mathrm{~m}^{3} /$ day, and above $>225 \mathrm{~m}^{3} /$ day are in the areas with good and excellent groundwater potentials, whereas borehole yields 
between 155 and $<55 \mathrm{~m}^{3} /$ day are in the areas with moderate and poor groundwater potentials simultaneously.

The results verification clearly shows the efficiency of the integrated remote sensing and GIS approaches incorporated in this research as a useful tool for identification of suitable locations for groundwater extraction, proper management and sustainable development. However, it is perceived that the current methodology can be used as a prospective guideline for groundwater exploration and exploitation in both hard and soft rock terrains.

\section{Compliance with ethical standards}

Conflict of interest No conflict of interest among the authors in this research.

\section{References}

1. Adeleye DR (1973) The geology of the middle Niger basin. In: Kogbe CA (ed) Geology of Nigeria. Elizabethan Press, Lagos, pp 283-287

2. Adeniji AE, Obiora DN, Omonona OV, Ayuba R (2013) Geoelectrical evaluation of groundwater potentials of Bwari basement area, Central Nigeria. Int J Phys Sci 8(25):1350-1361

3. Adiat KAN, Nawawi MNM, Abdullah K (2012) Assessing the accuracy of GIS-based elementary multi criteria decision analysis as a spatial prediction tool-a case of predicting potential zones of sustainable ground water resources. J Hydrol 440-441:75-89

4. Agagu OK, Fayose EA, Petters SW (1985) Stratigraphy and sedimentation in the Senonian Anambra Basin of eastern Nigeria. J Min Geol 22(1):26-36

5. Aku MO, Gani LI (2015) Geophysical investigation of the subsurface condition of the permanent site of Federal University Lokoja, Kogi State. Int J Sci Res Publ 5:1-6

6. Aluko OE, Igwe $O$ (2017) An integrated geomatics approach to groundwater potential delineation in the Akoko-Edo Area, Nigeria. Environ Earth Sci 76(1):1-14

7. Basavaraji H, Nijagunappa R (2011) Identification of groundwater zone using geoinformatics in Ghataprabha basin, North Karnataka, India. Int J Geomat Geosci 2(1):91-109

8. Chi KH, Lee BJ (1994) Extracting potential groundwater area using remotely sensed data and GIS techniques. In: Proceedings of the regional seminar on integrated applications of remote sensing and GIS for $L$ and water resources management, Bangkok. Economic and Social Commission for Asia and the Pacific, Bangkok, pp 64-69

9. Dessavagie FE (1972) Stratigraphy of the Niger Embankment near Bida, Nigeria. In: African geology. University of Ibadan Press

10. Edet AE, Okereke CS, Teme SC (1997) Application of remotesensing data to groundwater exploration: a case study of the Cross-River State, SE Nigeria. Hydrogeol J 6:394-404

11. Fashae OA, Tijani MN, Talabi AO, Adedeji OI (2014) Delineation of groundwater potential zones in the crystalline basement terrain of SW-Nigeria: an integrated GIS and remote sensing approach. Appl Water Sci 4:19-38

12. Jaiswal RK, Mukherjee S, Krishnamurthy J, Saxena R (2003) Role of remote sensing and GIS techniques for generation of groundwater prospect zones towards rural development. Int J Remote Sens 24(5):993-1008

13. Kehinde MO, Loenhert EP (1989) Groundwater resources studies in the Bida Basin, central Nigeria. In: A paper presented at the 1 st international water resources conference, Benin

14. Krishnamurthy JN, Manavalan P, Saivasan V (1992) Application of digital enhancement techniques for groundwater exploration in a hard rock terrain. Int J Remote Sens 13(15):2925-2942

15. Mekkil OA, Laftouhi N (2016) Combination of a geographical information system and remote sensing data to map groundwater recharge potential in arid to semi-arid areas: the Haouz Plain, Morocco. Earth Sci Inform 9:465-479

16. Mev-Hydrosearch (2001) Report of geophysical survey at $\mathrm{Mr}$ Agbele's Residence, Mopa, Kogi State. Mev-Hydrosearch and Engineering Services, Kaduna

17. Muralitharan J, Palanivel K (2015) Groundwater targeting using remote sensing, geographical information system and analytical hierarchy process method in hard rock aquifer system, Karur district, Tamil Nadu, India. Earth Sci Inform 8:827-842

18. Musa OK, Ogbodo DA, Jatto SS, Kudamnya EA (2013) Evaluation of groundwater potential of crystalline basement area of Kogi State Polytechnic, Osara Campus, North-Central Nigeria using electrical resistivity method. J Environ Earth Sci 3(9):171-182

19. Nigerian Meteorological Agency (NiMET) (2014) Seasonal rainfall prediction, March 2014, pp 38-42

20. Oh HJ, Kim YS, Choi JK, Park E, Lee S (2011) GIS mapping of regional probabilistic groundwater potential in the area of Pohang City, Korea. J Hydrol 399:158-172

21. Onimisi M, Daniel A (2014) Geophysical investigation of the precambrian marble occurrence in Itobe Area, Central Nigeria. Br J Appl Sci Technol 4(13):1891-1904

22. Onoja SO, Osifila AJ (2015) Integrated geophysical investigation of a suspected spring in Igbokoran, Ikare-Akoko, Southwestern Nigeria. J Appl Geol Geophs 3:83-91

23. Onsachi JM, Yakubu HM, Shaibu MM, Gyang DS (2016) Geophysical investigation of ground water potential in basement terrain, Okene North Central, Nigeria. Int J Emerg Trends Sci Technol 3:4266-4273

24. Pratap K, Ravindran KV, Prabakaran B (2000) Groundwater prospect zoning using remote sensing and geographical information system: a case study in Dala-Renukoot Area, Sonbhadra District Uttar Pradesh. J Indian Soc Remote Sens 28(4):249-263

25. Rahaman MA (1989) Review of the basement geology of Southwest Nigeria. In: Kogbe CA (ed) Geology of Nigeria. Rock View (Nig.) Limited, Jos, pp 39-56

26. Reyment RA (1965) Aspects of the geology of Nigeria. University of Ibadan, Ibadan, p 145

27. Saaty TL (1980) The analytical hierarchy process. McGraw Hill, New York

28. Selvam S, Dar FA, Magesh NS, Singaraja C, Venkatramanan Chung SY (2015) Application of remote sensing and GIS for delineating groundwater recharge potential zones of Kovilpatti Municipality, Tamil Nadu using IF technique. Earth Sci Inform 9:137-150

29. Shekwolo PD (1990) Development and maintenance of groundwater resources-Bida Basin case study. In: A paper presented at international seminar on hydrology, Maiduguri

30. Todd DK, Mays LW (2005) Groundwater hydrology, 3rd edn. Wiley, New York

31. Waiker ML, Nilawar AP (2014) Identification of groundwater potential zone using remote sensing and GIS techniques. Int J Innov Res Sci Eng Technol 3:12163-12174

Publisher's Note Springer Nature remains neutral with regard to jurisdictional claims in published maps and institutional affiliations. 